SJîñn Jurnal

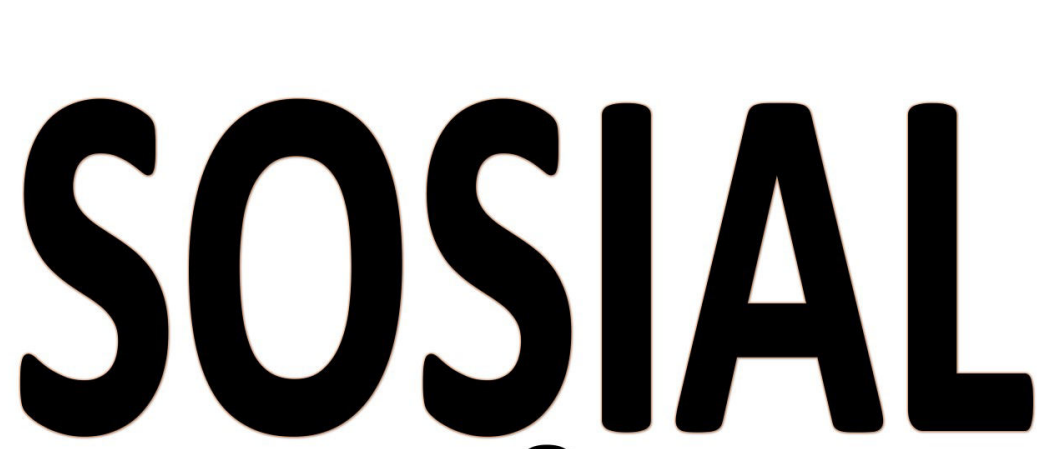

P-ISSN: 2356-1459 E-ISSN: 2654-9050 Vol. 7 No. 2 (2020)
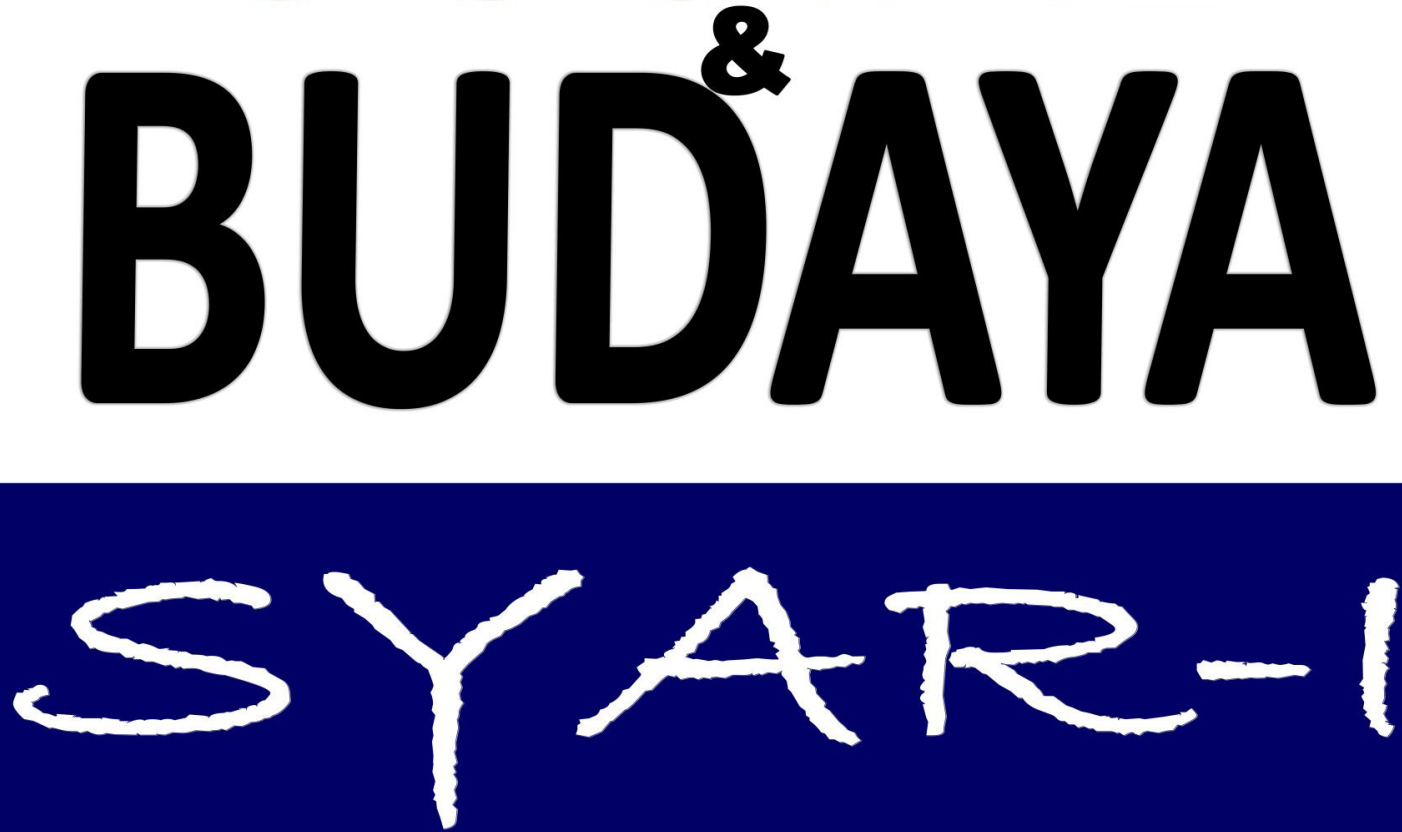

Hermeneutics On Hadith; Study on Muhammad lqbal Thought

Nur Khasanah, Achmad Irwan Hamzani, Havis Aravik

Islam Nusantara dan Gagasan Membumikan Islam: Respon Atas Perubahan Sosial Dan Kebhinnekaan Muhamad bin Abdullah Alhadi, Najwaa Chadeeja Alhady

Analisa Mekanisme Pasar Kalangan Pada Masyarakat Islam Melayu Di Kecamatan Gandus Palembang Meriyati, Choiriyah, Richa Angkita Mulyawisdawati

Penerapan E-Voting Dalam Sistem Pemilihan Umum Sebagai Optimalisasi Pelayanan Publik Di Era Revolusi Industri 4.0

Imas Novita Juaningsih, Muhammad Saef El-Islam, Adit Nurrafi

Identitas 'Kota Santri' Kabupaten Gresik melalui Gerak Tari Si'ar

Wiwik Istiwianah, Haris Suprapto, Anik Juwariyah

Peran Lembaga Alternatif Penyelesaian Sengketa dalam Menyelesaikan Sengketa Ekonomi Syariah Mukharom, Dharu Triasih, Dian Septiandani

Kondisi Perlindungan Konsumen Di Negara Indonesia Pada Tahun 2019

M. Makhfudz 


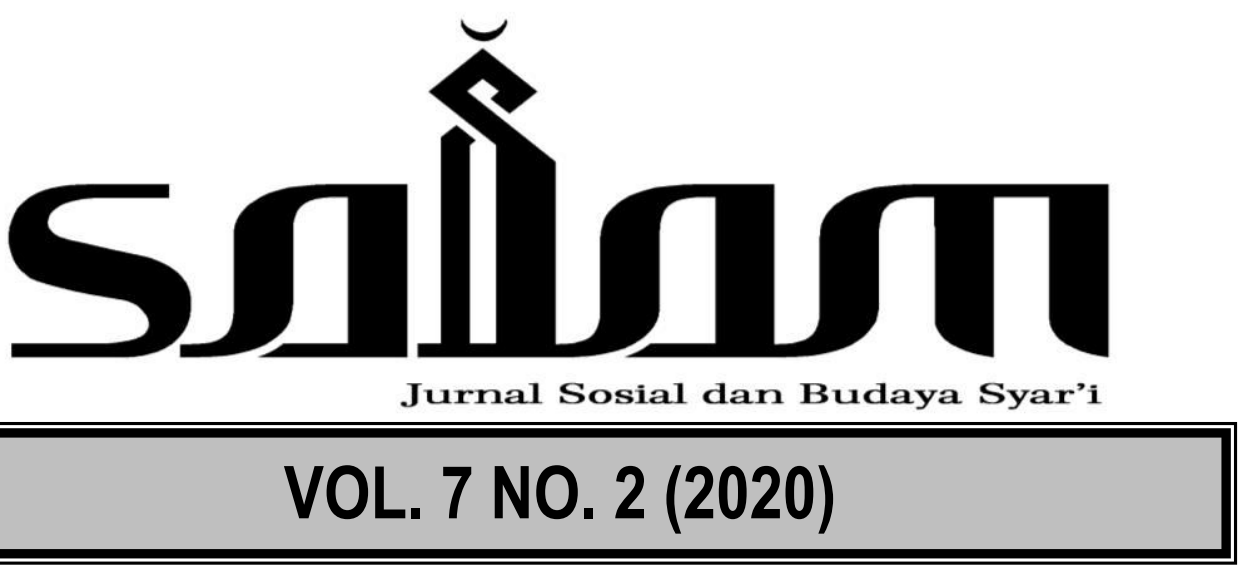

Diterbitkan oleh Fakultas Syariah dan Hukum Universitas Islam Negeri (UIN) Syarif Hidayatullah Jakarta.

Salam; Jurnal Sosial dan Budaya Syar-i mengkhususkan diri dalam pengkajian ilmu-ilmu Sosial dan Budaya dalam dimensi Syariah.

Terbit tiga kali dalam satu tahun di setiap bulan April, Agustus, dan Desember.

\section{Redaktur Ahli}

Muhammad Amin Suma (UIN Syarif Hidayatullah Jakarta) A Salman Maggalatung (UIN Syarif Hidayatull ah Jakarta) Asep Saepudin Jahar (UIN Syarif Hidayatullah Jakarta) Ahmad Mukri Aji (UIN Syarif Hidayatullah Jakarta) JM Muslimin (UIN Syarif Hidayatullah Jakarta) Muhammad Munir (IIU Islamabad Pakistan)

Euis Amalia (UIN Syarif Hidayatullah Jakarta)

Tim Lindsey (Melbourne University Australia)

Raihanah Azahari (University Malaya Malaysia)

Ahmad Tholabi (UIN Syarif Hidayatullah Jakarta)

Ahmad Hidayat Buang (University Malaya Malaysia)

\section{Pemimpin Redaksi \\ Erwin Hikmatiar}

\section{Sekretaris Redaksi}

Muhammad Ishar Helmi

Redaktur Pelaksana

Mara Sutan Rambe

Indra Rahmatullah

Nur Rohim Yunus

\section{Tata Usaha}

Imas Novita Juaningsih

Azizah Ratu Buana

\section{Alamat Redaksi}

Fakultas Syariah dan Hukum UIN Syarif Hidayatullah Jakarta Jl. Ir. H. Juanda 95 Ciputat Jakarta 15412 Telp. (62-21) 74711537, Faks. (62-21) 7491821

Website: www.fsh-uinjkt.net, E-mail: jurnal.salam@uinjkt.ac.id

Permalink: http://journal.uinjkt.ac.id/index.php/salam 


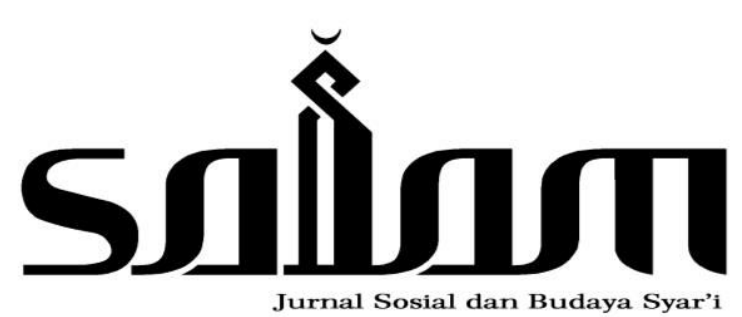

Menyambut baik kontribusi dari para ilmuwan, sarjana, profesional, dan peneliti dalam disiplin ilmu hukum untuk dipublikasi dan disebarluaskan setelah melalui mekanisme seleksi naskah, telaah mitra bebestari, dan proses penyuntingan yang ketat. 


\section{DAFTAR ISI}

\section{5-116}

Hermeneutics On Hadith; Study on Muhammad Iqbal Thought

Nur Khasanah, Achmad Irwan Hamzani, Havis Aravik

\section{7-130}

Islam Nusantara dan Gagasan Membumikan Islam: Respon Atas Perubahan Sosial Dan Kebhinnekaan

Muhamad bin Abdullah Alhadi, Najwaa Chadeeja Alhady

\section{1-140}

Analisa Mekanisme Pasar Kalangan Pada Masyarakat Islam Melayu Di Kecamatan Gandus Palembang

Meriyati, Choiriyah, Richa Angkita Mulyawisdawati

\section{1-162}

Penerapan E-Voting Dalam Sistem Pemilihan Umum Sebagai Optimalisasi Pelayanan Publik Di Era Revolusi Industri 4.0

Imas Novita Juaningsih, Muhammad Saef El-Islam, Adit Nurrafi

\section{3-182}

Identitas 'Kota Santri’ Kabupaten Gresik melalui Gerak Tari Si’ar

Wiwik Istiwianah, Haris Suprapto, Anik Juwariyah

\section{3-196}

Peran Lembaga Alternatif Penyelesaian Sengketa dalam Menyelesaikan Sengketa Ekonomi Syariah

Mukharom, Dharu Triasih, Dian Septiandani

\section{7-210}

Kondisi Perlindungan Konsumen Di Negara Indonesia Pada Tahun 2019

M. Makhfudz 



\title{
Islam Nusantara dan Gagasan Membumikan Islam; Respon Atas Perubahan Sosial dan Kebhinnekaan*
}

\author{
Muhamad bin Abdullah Alhadi, ${ }^{1}$ Najwaa Chadeeja Alhady ${ }^{2}$ \\ Institut Pembina Rohani Jakarta (IPRIJA) \\ doi $10.15408 /$ sjsbs.v7i2.14881
}

\begin{abstract}
Community in various activities will bring social change, then every social change generally causes changes in system and legal values. Islam came and responded to these changes, opening widely the possibility of reforming Islamic teachings or Islamic law in accordance with the conditions and needs of the people. Ijtihad conception in Islamic teachings has formulas and rules that have been established, which are intended to create the welfare of the people and the awareness from new influences coming from outside of Islam --especially social change and diversity. This paper not only reveals the Islamic response in general, but also discusses the role of Indonesian Muslim scholars in responding to these changes and diversity.
\end{abstract}

Keyword: Islam nusantara, social change, diversity

\begin{abstract}
Abstrak
Masyarakat dengan berbagai keragaman aktifitas yang dilakukan akan membawa perubahan sosial, dan setiap perubahan sosial pada umumnya menyebabkan perubahan nilai sistem dan hukum. Islam datang dan memberikan respon perubahan-perubahan tersebut, membuka secara luas kemungkinan untuk mereformasi ajaran Islam atau hukum Islam sesuai dengan kondisi dan kebutuhan umat. Pembaruan pemikiran (ijtihad) dalam ajaran Islam memiliki rumusan dan aturan yang telah ditetapkan, yang dimaksudkan untuk menciptakan kesejahteraan masyarakat dan kesadaran akan pengaruh baru yang datang dari luar Islam -terutama perubahan sosial dan sikap atas keberagaman. Tulisan ini tidak hanya mengungkapkan respons Islam secara umum, namun juga mendiskusikan peran cendikiawan Muslim di Indonesia dalam menanggapi perubahan dan kebhinnekaan tersebut.
\end{abstract}

Kata Kunci: Islam Nusantara, Perubahan Sosial, Kebhinnekaan

${ }^{*}$ Diterima: 19 Februari 2020, Revisi: 26 Februari 2020, Diterbitkan 20 Maret 2020.

${ }^{1}$ Muhamad bin Abdullah Alhadi adalah Mahasiswa S3 Pengkajian Islam, UIN Syarif Hidayatullah Jakarta dan Dosen Institut Pembina Rohani Jakarta (IPRIJA), E-mail: moeh.alhady@gmail.com.

${ }^{2}$ Najwaa Chadeeja Alhady adalah Dosen Institut Pembina Rohani Jakarta (IPRIJA). 


\section{Pendahuluan}

Perubahan sosial merupakan sesuatu keniscayaan yang selalu dihadapi oleh manusia dalam sejarah kehidupannya. ${ }^{3}$ Dalam kajian sosiologi, perubahan sosial dalam masyarakat merupakan wacana utama dimana penelitian dan perbedaan pendapat terjadi diantara para ahli sosiologi. Selama manusia sebagai pendukung dan pelaku kehidupan sosial dan budaya masih hidup, selama itu pula perubahan akan terjadi. Kontak dengan budaya lain yang melahirkan difusi, utamanya penemuan-penemuan baru, perluasan yang cepat pada mekanisme pendidikan formal, intensitas konflik terhadap nilai-nilai yang ada akibat sistem sosial yang terbuka dan terbukanya antisipasi masa depan merupakan daya dorong utama terjadinya perubahan. ${ }^{4}$

Sementara itu dalam teori teologi keagamaan universal, menurut Mulkan ${ }^{5}$ semua agama mengajarkan untuk berbuat baik kepada semua kalangan. Tentu saja agama tersebut diposisikan sebagai dasar menuju terciptanya kesalehan sosial. Sebagai bagian dari sistem sosial, Islam meyakini perubahan sebagai suatu realitas yang tidak bisa diingkari. Islam memberikan tempat yang paling tepat demi memudahkan semua hal agar beradapasi dengan perubahan secara shahih dan aman. Agama berjalan bersama beriringan dengan lajunya kehidupan. Tugas agama adalah mengawal perubahan secara benar untuk kemaslahatan hidup manusia. Disinilah sesungguhnya tugas seorang cendekiawan muslim untuk merumuskan pendekatan dan metodologi yang tepat sesuai dengan konteks yang melingkupinya agar agama menjadi fungsional dan bisa membumi. Oleh karena itu, Islam harus diperlakukan sebagai sebuah kekuatan yang bersifat inklusif, demokratis, dan pluralis yang dibutuhkan dalam membangun suatu bangsa.

Berangkat dari keyakinan tersebut, corak pemikiran Islam juga harus memiliki paradigma pergerakan sosio-kultural dengan berupaya menampilkan sosok Islam dalam kesadaran hidup sehari-hari dan membangun sistem kelembagaan masyarakat. Gerakan sosial kebudayaan (socio-cultural) cenderung menjelma menjadi gerakan penyadaran dan pemberdayaan masyarakat serta sistem kelembagaannya sebagai komitmen terhadap demokrasi dan terbentuknya masyarakat sipil mandiri. Melalui pemikiran Islam sebagai kekuatan kultural ini, maka Islam akan dapat ditampilkan sebagai social salvation (penyelamatan sosial). ${ }^{6}$

${ }^{3}$ Jelamu Ardu Marius, “Perubahan Sosial," Jurnal Penyuluhan 2, no. 2 (2006): 125-35.

${ }^{4}$ Dalam terminologi filsafat, yang pasti hanyalah perubahan. Heraklitus, seorang filsuf Yunani yang hidup 26 abad yang lalu mengatakan bahwa tidak ada tidak berubah kecuali perubahan itu sendiri (Nothing endures but change). Perubahan merupakan suatu yang sina qua none dalam kehidupan. Hanya karena umur dan tempat manusia yang "terbatas", manusia tidak dapat melihat perubahan secara kasat mata. Jika kita melihat sepanjang sejarah perjalanan manusia, maka kita akan dengan mudah melihat serpihan perubahan tersebut. T. Kippenberger, “Nothing endures but change," The Antidote 3, no. 4 (1998): 4-5.

${ }^{5}$ Abdul Munir Mulkhan, Teologi kebudayaan dan demokrasi modernitas (Pustaka Pelajar, 1995), 76

${ }^{6}$ Persoalan apapun yang dihadapi masyarakat Islam harus ditampilkan sebagai faktor nilai yang menjadi komplemen bagi nilai-nilai yang lain dalam memberantas segala bentuk ketertindasan dan kemunduran masyarakat. Syamsul Bakri, “Agama, Persoalan Sosial, dan Krisis Moral,” KOMUNIKA 3, no. 1 (2009): 37-45. 


\section{Respon Islam Terhadap Perubahan Sosial dan Keragaman Masyarakat}

Bekford mengungkapkan asumsi bahwa agama sangat personal dan sosial yang bersifat tidak terhindarkan (unavoidably social). Tidak ada pertentangan antara ide agama atau keyakinan dengan kepribadian manusia, identitas dan nasib --terpola secara sosial. Dalam hal ini praktek keagamaan menunjukan pola yang luas mencerminkan kejadian pola sosial masyarakat. Munculnya gagasan pergerakan keagamaan menyiratkan suatu upaya memperkenalkan perubahan dalam agama. ${ }^{7}$

Perubahan dalam agama mungkin terjadi pada seluruh agama, tidak hanya Islam. ${ }^{8}$ Bahkan Islam dapat diposisikan sebagai inti perubahan tersebut, perubahan ekstrim membebaskan manusia dari kegelapan menuju cahaya benderang (min azzulumati ila an-nur). Ruang lingkup perubahan-perubahan sosial meliputi unsur-unsur kebudayaan baik yang material maupun yang non-material. Hal yang ditekankannya adalah pengaruh besar unsur-unsur kebudayaan material terhadap unsur-unsur nonmaterial. Dengan pengertian ini sebenarnya Ogburn mengatakan bahwa perubahanperubahan sosial terkait dengan unsur-unsur fisik dan rohaniah manusia akibat pertautannya dengan dinamika manusia sebagai suatu totalitas. Perubahan pola pikir, pola sikap dan pola tingkah laku manusia (yang bersifat rohaniah) lebih besar dipengaruhi oleh perubahan-perubahan kebudayaan yang bersifat material. ${ }^{9}$

Merupakan diktum yang tak terbantahkan bahwa Islam adalah agama yang salihun li kulli zaman wa makan. Sejak awal, keberadaan Islam memang dipandang sebagai agama yang mampu berinteraksi dengan ruang dan waktu. Demikian ini karena Islam bersifat universal. Universalitas Islam terkait dengan karakteristik Islam yang rigid di satu pihak dan fleksibel di pihak lain (bayn al-tabat wa al-murunah). Menurut Harisuddin, ${ }^{10}$ karakteristik Islam yang demikian ini, menjadikan Islam lebih mudah diterima masyarakat di belahan dunia manapun.

${ }^{7}$ James A. Beckford, New religious movements and rapid social change (Sage, 1986), ix-x.

${ }^{8}$ Kelahiran Kristen Protestan, misalnya tidak lepas dari hasil pembaruan terhadap ajaran Kristen Katolik. Bentuk yang lebih jelas adalah munculnya banyak jenis atau cabang gereja yang ada di Indonesia (pada level provinsi) merupakan gereja yang bersifat kesukuan atau kedaerahan tertentu. Hal ini terjadi karena adanya politik gospel masa lalu oleh pihak penjajah (Portugal ataupun Belanda) yang memakai taktik pendekatan suku. Gereja kesukuan/kedaerahan ini berciri kedaerahan atau kesukuan tertentu menurut adat istiadat daerah setempat. Bentuk lain perubahan adalah kehadiran ajaran/aliran sempalan pada hampir seluruh agama, aliran baru tersebut merupakan wadah yang dipersiapkan untuk menampung kebutuhan pemeluknya yang tidak terpuaskan oleh ajaran yang diyakini sebelumnya. Baca Abbas Langaji, "Dinamika Aliran Keagamaan Sempalan: Tinjauan Perspektif Sosiologi Agama," 2012; Nunu Burhanuddin, "Tipologi Gerakan Sempalan di Kalangan Umat Islam Indonesia: Analisis Sosiologis dan Fungsional," in Annual Conference on Islamic Studies in Banjarmasin, South Kalimantan, Indonesia, on, 2010, 1-4; M. M. van Bruinessen, "Gerakan sempalan di kalangan umat Islam Indonesia: latar belakang sosial-budaya," 2007.

${ }^{9}$ Marius, "Perubahan Sosial," 75.

${ }^{10}$ M. Noor Harisudin, "Rekonstruksi Fiqh dalam Merespon Perubahan Sosial," Asy-Syir'ah 50, no. 1 (2016): 81-107. 
Azyumardi Azra mengklasifikasikan respons Islam terhadap modernisme dan modernisasi Barat dalam tiga bentuk, yakni pertama, apoligetik, kedua identifikatif dan ketiga afirmatif. ${ }^{11}$

Terhadap hal-hal yang bersifat dogmatik, maka doktrin-doktrin Islam tidak dapat diubah sepanjang zaman. Ajaran seperti sholat, puasa Ramadhan, haji, dan lain sebagainya merupakan ibadah yang ghayr ma'qul al-ma'na (unreasonable). Sementara, halhal ihwal manusia senantiasa berubah sesuai dengan perkembangan zaman. Salah satu contoh adalah dalam praktek mu'amalah, terdapat kaidah al-ashlu fi al-mu'amalat alibahah hatta yadulla al-dalilu 'ala tahrimiha' ${ }^{12}$ menunjukkan fleksibilitas tata hukum niaga dalam perspektif fikih. Ini bisa dimaklumi karena perkembangan dalam bidang mu'amalah sangat cepat. Karena itu, mu'amalah merupakan dimensi yang ma'qul al$m a^{\prime} n a$ (reasonable) dan akan terus berkembang seiring dengan perkembangan zaman. Konsep perubahan sosial dan modal manusia mempunyai kaitannya dengan konsep Islam berperadaban (hadhari). Konsep ini merupakan penggalian dari gagasan Ibnu Khaldun, sebagaimana dikemukakan Majid dan Rahim. ${ }^{13}$

Dalam persfektif sejarah, menurut dinamika hukum Islam khususnya di Indonesia menunjukan fenomena transformatif dan remedialis secara mendasar dilihat dari kesinambungan dan perubahannya. ${ }^{14}$ Marx Weber dan Emile Durkheim mengemukakan pandangan bahwa "hukum merupakan cerminan dari solidaritas yang ada dalam suatu masyarakat." 15 Soekanto menguatkan pendapat Weber dan Durkheim tentang perubahan sosial yang berhubungan dengan perubahan hukum. Perubahan hukum itu akan dipengaruhi oleh tiga faktor, yakni: ${ }^{16}$

1. Adanya komulasi progresif dari penemuan-penemuan di bidang teknologi.

2. Adanya kontak atau konflik antar kehidupan masyarakat.

3. Adanya gerakan sosial (social movement).

Berdasarkan teori yang dikutip diatas, maka jelas bahwa hukum ada sebagian besar karena merupakan akibat dari pada faktor-faktor penyebab terjadinya perubahan sosial. Menurut Fuad, ${ }^{17}$ hubungan antara hukum Islam dengan perubahan sosial

${ }^{11}$ Azyumardi Azra, Pergolakan Politik Islam: dari Fundamentalisme, Modernisme hingga Posmodernisme (Jakarta: Paramadina, 1996), iv-vi.

12 Abdul Wahab Khalaf, “Ilm usul al-Fiqh,” Kuwait: Darul Qalam, 1978, 62.

13 Teori yang menegaskan masyarakat sebagai suatu organisme yang bersifat hidup, mempunyai potensi untuk berubah dan berkembang maju seandainya perancangan pembangunan yang rapi dan tersusun dapat dilakukan. Mohd Kamil Abd Majid dan Rahimin Affandi Abdul Rahim, "Perubahan Sosial Dan Impaknya Terhadap Pembentukan Modal Insan Menurut Ibn Khaldun," Jurnal Hadhari 1 (2008): 1-38.

${ }^{14}$ Geliat pemikirannya bukan sekedar tambal sulam ide, melainkan sudah seperti bola salju yang terus menggelinding, melaju, mengkonstruksi berbagai tipe dan karakter baru. Mahsun Fuad, Hukum Islam Indonesia: dari nalar partisipatoris hingga emansipatoris (PT LKiS Pelangi Aksara, 2005), 1-9.

${ }^{15}$ Fathullah Fathullah, "Hukum Islam dan Perubahan Sosial," As-Syari'ah: Jurnal Hukum Islam 2, no. 2 (2016): 35-49.

${ }^{16}$ Ia menguatkan pendapat Arnold Rose. Soekanto Soerjono, "Pokok-Pokok Sosiologi Hukum," Jakarta: Rajawali Pers, 1980, 96.

${ }^{17}$ Muhammad Khalid Masud, “Filsafat Hukum Islam: Studi tentang Hidup dan Pemikiran Abu Ishaq al-Syathibi, terj," Ahsin Muhammad, cet 1 (1996): 1-2; Susan Elizabeth Rayner, "The theory of contracts in 
setidaknya akan menghasilkan dua teori yang berbeda. Pertama, teori keabadian (normativitas). Menurut teori ini hukum Islam akan tetap abadi, konstan serta tidak akan mengalami perubahan dari zaman sebagaimana diturunkannya hukum tersebut. Oleh karenanya, ia tidak bisa diadaptasikan dengan perubahan sosial. Selamanya, hukum Islam ini tidak akan berubah. Kedua, teori adaptabilitas (perubahan) yang menyakini hukum Islam dapat disesuaikan dengan perubahan sosial yang terjadi dan membutuhkan ijtihad baru yang lebih sesuai dengan realitas sosial (al-waqi') dan sebagai respon terhadap perubahan sosial. Adaptabilitas dalam hal ini dapat dipahami mengacu pada dua kerangka, yakni kemungkinan perluasan hukum yang sudah ada dan keterbukaan satu kumpulan hukum bagi perubahan.

Dari kedua teori ini, teori adaptabilitas lah yang dipandang lebih kuat secara dalil. Sementara, teori keabadian hukum sangat lemah dari banyak sisi. Hal ini disebabkan karena ruang (al-makan) dan waktu (al-zaman) mempunyai andil besar dalam proses inferensi hukum (istinbat al-hukm) bagi para mujtahid.

Pengaruh perubahan sosial nampak semakin jelas dapat menimbulkan perubahan dalam sistem pemikiran Islam, termasuk di dalamnya pembaruan hukum Islam. Sehingga tanpa upaya pembaruan terhadap hukum Islam, maka dapat menimbulkan berbagai kesulitan dalam memasyarakat dan keberlangsungan ajaran Islam pada umumnya. ${ }^{18}$

Sumber hukum normatif- tekstual Islam yang telah ditetapkan sangat terbatas jumlahnya, sementara kasus-kasus baru di bidang hukum terus muncul di tengahtengah masyarakat dalam jumlah yang tidak terbatas. Menurut Ibnu Rusyd persoalanpersoalan kehidupan masyarakat tidak terbatas jumlahnya, sementara jumlah nash (baik al-Qur'an dan al-Sunah), jumlahnya terbatas. Oleh karena itu menurutnya mustahil sesuatu yang terbatas jumlahnya mampu menghadapi sesuatu yang tidak terbatas. ${ }^{19}$

Pernyataan Ibnu Rusyd tersebut mengandung pesan dan semangat untuk melakukan ijtihad terhadap kasus-kasus hukum baru yang tidak dijelaskan sumber hukumnya dalam nash baik al-Qur'an maupun al-Sunah secara eksplisit. Dengan demikian, aktivitas ijtihad dalam Islam dapat dipandang sebagai satu-satunya jalan untuk merespon dinamika perubahan zaman dengan berbagai kompleksitas persoalannya yang memasuki seluruh dimensi kehidupan manusia. Dalam hukum Islam, perubahan sosial budaya dan letak geografis menjadi variabel penting yang ikut mempengaruhi adanya perubahan hukum. Ibnu Qayyim al-Jauziyah menyatakan bahwa "Berubahnya hukum dikarenakan berubahnya zaman, tempat, kebiasaan dan niat."20

Salah satu bukti konkret betapa faktor lingkungan sosial budaya berpengaruh terhadap hukum Islam adalah munculnya dua pendapat Imam Syafi'i yang dikenal dengan qaul qadim dan qaul jadid. Pendapat lama (qaul qadim) adalah pendapat hukum

\footnotetext{
Islamic law: a comparative analysis with particular reference to the modern legislation in Kuwait, Bahrain and the United Arab Emirates." (University of Cambridge, 1989), 33-34.

${ }^{18}$ S. H. I. Imdad, "Hukum Islam dan Perubahan Sosial," t.t.

${ }^{19} \mathrm{Ibn}$ Rusyd, Muhammad, Bidayat al-Mujtahid wa Nihayat al-Muqtashid (Beirut: Dar al-Qalam, 1988), 2.

20 Ibn Qayyim al-Jauziyah, I'lam al-Muawaqi'in 'an Rabbi al-'Alami>n (Bairut, Daar al-Fikr), 14. Menyatakan: تغير الاحكام بتغير الازمنة والامكنة والاحو ال والعو اعدو والنيات
} 
Imam Syafi'i ketika beliau berada di Baghdad. Menurut Najitama hal-hal yang melatarbelakangi timbulnya dua pendapat imam Syafi'i adalah sebagai berikut: ${ }^{21}$

1. Faktor geografis. Faktor geografi sangat menentukan terhadap perkembangan dan pembentukan hukum Islam. Faktor geografis yang sangat menentukan tersebut adalah iklim dan perkembangan daerah itu sendiri. Seperti telah diketahui iklim di Hijaz berbeda dengan iklim di Iraq dan berbeda pula dengan iklim yang ada di Mesir, sehingga melahirkan fatwa Imam Syafi'i yang berbeda. Adanya qaul qadim dengan qaul jadid, membuktikan adanya berbedanya iklim dan geografi.

2. Faktor Kebudayaan dan Adat Istiadat. Faktor kebudayaan dan adat istiadat sangat mempengaruhi terhadap pertumbuhan dan perubahan hukum Islam. Setelah banyaknya negara-negara yang dikuasai oleh Islam, padahal negaranegara yang dikuasai tersebut telah memiliki kebudayaan-kebudayaan dan adatistiadat masing-masing yang tidak bisa ditinggalkan begitu saja, kebudayaan dan adat-istiadat mereka telah menyatu. Oleh karena itu asimilasi (percampuran) antara kebudayaan (adat istiadat) setempat dengan kebudayaan Islam sering terjadi, sehingga menimbulkan akibat lain dari hukum Islam itu sendiri. Walaupun masyarakat telah mempunyai kebudayaan-kebudayaan lain yang mempengaruhinya, namun para ahli fikih dapat pula menimbulkan pengaruh baru, karena adanya dua faktor yang mempengaruhi perkembangan fiqh di daerah-daerah itu, pertama milieu (lingkungan), ke dua sistim yang ditempuh oleh ahli fikih dalam memberikan hukum. Penafsiran-penafsiran itu lahir sesuai dengan susunan masyarakat yang ada ditempat dan jaman itu muncul. Jaman terus menerus membawa perubahan pada suasana masyarakat. Oleh karena itu ajaran bukan dasar yang timbul sebagai pemikiran dijaman tertentu belum tentu sesuai untuk zaman lain.

3. Faktor Ilmu Pengetahuan. Faktor Ilmu Pengetahuan bisa mempengaruhi hasil ijtihad para imam mujtahid dalam menggali hukum dan menentukan hukum. Imam Syafi'i seorang yang ahli hadits, beliau belajar hadits kepada Imam Malik bin Anas di Madinah, Imam Syafi'i juga seorang ahli $r a^{\prime} y u$, karena beliau belajar kepada Imam Abu Yusuf dan Imam Muhamamd bin Hasan murid Imam Abu Hanifahdi Iraq. Dengan faktor ilmu pengetahuan Imam Syafi'i tersebut, maka hasil ijtihad Imam Syafi'i tidak sama dengan gurunya yang ahli hadits maupun dengan ahli $r a^{\prime} y u$.

Ringkasnya Perbedaan pendapat hukum dalam masalah yang sama dari seorang Mujtahid Imam Syafi'i jelas disebabkan faktor keilmuan yang dimiliki, struktur sosial, budaya dan letak geografis yang berada antara daerah Iraq (Baghdad) dan Mesir.

Dalam konteks historis, pemikiran bidang hukum Islam sesungguhnya memperlihatkan kekuatan yang dinamis dan kreatif dalam mengantisipasi setiap perubahan dan persoalan-persoalan baru. Hal ini dapat dilihat dari munculnya

21 Fikria Najitama, "Sejarah Pergumulan Hukum Islam dan Budaya serta Implikasinya bagi Pembangunan Hukum Islam Khas Indonesia," Al-Mawarid 17 (2007). 
sejumlah madzhab hukum yang memiliki corak sendiri-sendiri sesuai dengan latar belakang sosio-kultural dan politik dimana madzhab itu tumbuh dan berkembang. Warisan monumental yang sampai sekarang masih memperlihatkan akurasi dan relevansinya adalah kerangka metodologi penggalian hukum yang mereka ciptakan. Dengan perangkat metodologi tersebut, segala permasalahan bisa didekati dan dicari legalitas hukumnya dengan metode qiyas, maslahah al-mursalah, istihsan, istishab, dan 'urf. Dalam posisi demikian, hukum Islam akan berfungsi sebagai rekayasa sosial (social engineering) untuk melakukan perubahan dalam masyarakat.22

Untuk menempatkan hukum pada posisi yang betul-betul fungsional dalam menghadapi setiap perubahan sosial, diperlukan terobosan metodologis disertai kemampuan membaca fenomena zaman. Banyak perangkat ilmu bantu yang bisa menopang perumusan hukum menjadi aplikatif, seperti ilmu-ilmu tafsir, tarikh, dan ilmu tata bahasa Arab. Diharapkan melalui pendekatan konvergensi antara ilmu ushul figh dan ilmu-ilmu lainnya akan dapat mengurangi formalisme hukum Islam.

Dalam konteks tersebut, pemaknaan hukum Islam tidak harus dilihat dari perspektif nilai saja, tetapi perlu dicari keterkaitan secara organik dan struktural dalam kehidupan sosial. Di sini lah letak pentingnya fenomena transformasi pemikiran hukum Islam, tidak hanya dilihat sebagai fenomena keagamaan saja, sebagaimana terlihat dari perjalanan panjang sejarah..$^{23}$

Transformasi pemikiran merupakan suatu pergumulan kreatif antara Islam dengan masyarakatnya, antara nilai-nilai Islam dengan kenyataan struktural masyarakat. Oleh karena itu, maka program pembaruan pemikiran hukum Islam adalah suatu bagian yang tidak terpisahkan dari proses kehidupan masyarakat yang selalu berubah. Akan tetapi, untuk melakukan upaya pembaruan pemikiran hukum Islam (fiqh) diperlukan beberapa syarat, yaitu; pertama, adanya tingkat pendidikan yang tinggi dan keterbukaan dari masyarakat muslim; kedua, hukum Islam (fiqh) harus dipandang sebagai variasi suatu keragaman yang bersifat partikular yang selalu dibatasi oleh dimensi ruang dan waktu; ketiga, memahami faktor sosio-kultural dan setting politik yang melatar belakangi lahirnya suatu produk hukum agar dapat memahami partikularisme dari pemikiran hukum tersebut; keempat, mengorientasikan istinbat hukum dari aspek qaulan (materi hukum) kepada aspek manhaj (kerangka metodologis). Disamping itu, perlu juga memahami pemikiran hukum yang tidak dibatasi sekat-sekat madzhab. Keterbatasan alternatif yang dibingkai dengan sekat madzhab akan menghasilkan produk pemikiran yang rigid (kaku) dan akan mempersulit upaya pembaruan hukum Islam itu sendiri.

Lain halnya dengan menempatkan Islam sebagai social salvation, maka agama ini akan lebih dapat membumi dan melebarkan sayap-sayap nilainya sehingga tidak dianggap agama primitif yang jauh dari dinamika persoalan sosio-historis. Islam harus diperankan dalam kerangka pembebasan yaitu pembebasan masyarakat dari

${ }^{22}$ Sakirman Sakirman, “Meretas Kebekuan Ijtihad Dalam Konstruksi Fiqih Sosial,” Mizani 25, no. 1 (2015).

${ }^{23}$ Wahyu Abdul Jafar, "Ijtihad Dalam Bentang Sejarah Prakodifikasi Ushul Fiqh," Nizham Journal of Islamic Studies 2, no. 1 (2017): 44-62. 
kemiskinan, pelanggaran, keterbelakangan, sebagainya. Perkembangan dunia dalam berbagai bidang pengetahuan yang semakin maju seperti medis, hukum, sosial dan ekonomi dan disertai dengan era globalisasi telah membawa pengaruh yang besar, termasuk dalam persoalan-persoalan hukum. Islam dan masyarakat Islam sebagai suatu bagian yang tidak terpisahkan dari dunia, tidak dapat melepaskan dari persoalanpersoalan yang menyangkut kedudukan hukum suatu persoalan. ${ }^{24}$

Respon cepat para pemikir Muslim dalam mensikapi perubahan tidak selalu berjalan mulus. Menurut Fawahid, kebebasan berfikir ternyata harus siap berhadapan dengan kuatnya "otoritas resmi" elit politik ataupun elit agama-yang senantiasa mengutamakan hak definitif dalam menafsirkan agama pada dirinya. Usaha-usaha kreatif yang dilandasi semangat memenuhi kebutuhan hidup saat ini bahkan dituduh sebagai sebab pendangkalan agama. ${ }^{25}$

\section{Islam Nusantara Sebagai Respon atas Kebhinnekaan}

Menurut Ramadhan, ${ }^{26}$ jika Islam and the West memperhadapkan antara Islam dan Barat, maka Islam in the West tidak nampak lagi seperti itu. Yang ada adalah hubungan Islam dan Barat yang cair karena Islam adalah bagian dari Barat. ${ }^{27}$ Sejalan dengan konsep Ramadan, di Indonesia lahir "Islam Nusantara", sebagai jawaban solutif membumikan Islam di tengah keragaman nusantara.

Wacana Islam Nusantara disuarakan oleh Azra pada tahun 2002,28 dan mulai menggema dalam dua tahun terakhir. ${ }^{29}$ Islam Nusantara dipahami sebagai Islam yang telah mengalami "pribumisasi" atau nativization sehingga ajarannya lebih sesuai dengan kepribadian dan jati diri bangsa Indonesia. Karakter yang sering disematkan kepada

${ }^{24}$ Bakri, "Agama, Persoalan Sosial, dan Krisis Moral."

${ }^{25}$ Apa yang dialami oleh Mahmoud Muhammed Taha di Sudan, Subhi al Shalih di Libanon, dan Farag Fuda di Mesir, misalnya, menjadi bukti nyata betapa rezim pemaknaan hanyalah "hak suci" otoritas tertentu. Hadirnya gagasan kreatif yang berupaya mendobrak kekakuan doktrinal pemaknaan agama dicap sebagai "menentang kehendak Tuhan". Stigma "menentang kehendak Tuhan" tampak menjadi senjata ampuh untuk memasung nalar kritis. Ah Fawaid, "Tradisi Ijtihad: Mengembalikan Semangat Progresivitas Islam," ULUL ALBAB Jurnal Studi Islam, 2013.

${ }^{26}$ Konsep ini adalah kritikan terhadap konsep Islam dan Barat yang seakan-akan memandang Islam dan Barat secara berhadap-hadapan. Konsep Islam di Barat tidak demikian, karena mengandaikan indentitas Islam dan eropa bukan bagian yang benar-benar terpisah sehingga terbuka kemungkinan untuk menyatu. Tariq Ramadan, Western Muslims and the future of Islam (Oxford University Press, 2003); Tariq Ramadan, Islam, the West and the Challenges of Modernity (Kube Publishing Ltd, 2009), 4-6.

${ }^{27}$ Abd. Muid N., Islam vs Barat: Merajut Identitas yang Terkoyak (Jakarta: Eurabia, 2013), 255-57.

${ }^{28}$ Pemikrian Azyumardi Azra dapat dibaca dalam buku Azyumardi Azra, Islam Nusantara: Jaringan Global dan Lokal (Mizan, 2002).

${ }^{29}$ Walaupun dianggap bukan istilah baru, istilah Islam Nusantara terakhir telah dikampanyekan secara gencar oleh Nahdlatul Ulama (NU), Presiden Joko Widodo saat berpidato dalam membuka Munas alim ulama NU di Masjid Istiqlal 2016, menyatakan dukungannya secara terbuka atas model Islam Nusantara. http://www.bbc.com/indonesia/berita_indonesia/2015/06/150614_indonesia_islam_nusantara. 
Islam Nusantara adalah ramah, anti-kekerasan, toleran, menghargai tradisi, dan menghargai kebangsaan. ${ }^{30}$

Dalam sejarah pemikiran Islam di Indonesia, cendikiawan muslim Indonesia telah banyak menawarkan pendekatan akomodatif dalam merespon perubahan dan kebhinnekaan tersebut pada ranah syariah. Sebagian hanya berupa wacana, sebagian telah diakomodasi dalam syariat. Tetapi bagaimana pun pemikiran dari tokoh-tokoh nusantara sepanjang masa itu, entah sebagai "jawaban," counter atau kritik, dapat masing-masing sebagai tawaran baru.

Diantara khazanah pemikiran pembaruan Nurcholish Madjid dikenal dengan pemikiran Sekularisasi Islam,31 Abdurrahman Wahid memperkenalkan konsep Pribumisasi Islam, ${ }^{32}$ Jalaluddin Rahmat menawarkan Islam Alternatif, 33 Amin Rais merumuskan Tauhid Sosial, ${ }^{34}$ Moeslim Abdurrahman mengusung Islam Transformatif. ${ }^{35}$ Muncul pula gagasan Ali Yafie dan Sahal Mahfudz yang menawarkan "fikih sosial",36 disamping "fikih kiri" 37 dan "fikih kebhinekaan" 38.

Kecenderungan pembaruan pemikiran di atas merupakan fase baru yang membedakannya dengan puluhan tahun sebelumnya. Pemikiran masa sebelumnya cenderung menjadikan Islam sebagai perjuangan politik ideologis, yang kemudian memaksa Islam di Indonesia harus diperhadapkan dengan negara dan ideologi-ideologi lain seperti nasionalisme dan sosialisme. Selama kurun waktu tersebut, dipandu tekanan suatu rezim politik yang sangat hegemonik terhadap umat Islam, harus diakui bahwa para pemikir muslim memang tampak mengerahkan seluruh daya kreativitas dan kritisisme berpikirnya dalam rangka penguatan pembaharuan pemikiran Islam, mengimbangi paksaan proyek modernisasi negara.

Menurut Madjid, pembaruan harus dimulai dengan dua tindakan yang saling erat hubungannya, yaitu melepaskan diri dari nilai-nilai tradisional, dan mencari nilainilai yang berorientasi ke masa depan. Dengan demikian orientasi dan kerinduan kepada masa lampau yang berlebihan, harus digantikan dengan pandangan yang berorientasi ke masa depan. ${ }^{39}$ Untuk membumikan konsepnya, Madjid mensyaratkan

${ }^{30}$ Ali Masykur Musa, Membumikan Islam Nusantara: Respons Islam terhadap Isu-Isu Aktual, 2014, 13292.

${ }^{31}$ Nurcholish Madjid, "Keharusan pembaruan pemikiran Islam dan masalah integrasi umat," Islam: Kemodernan dan Keindonesiaan, 1987, 204-14.

32 Abdurrahman Wahid, "Pribumisasi Islam” dalam Islam Indonesia Menatap Masa Depan," Jakarta: P3M, 1989, 45.

33 Jalaluddin Rahmat, Islam alternatif: ceramah-ceramah di kampus (Mizan, 1988), 96.

${ }^{34}$ M. Amin Rais, “Tauhid Sosial: Doktrin Perjuangan Muhammadiyah," dalam media Indonesia, Jurnal Universitas Muhammadiyah, Yogyakarta, no. 1 (1996): 56.

${ }^{35}$ Moeslim Abdurrahman, Islam Transformatif, Jakarta: Pustaka Firdaus. 1995 (Jakarta: Pustaka Firdaus, 1995), 34.

36 Ali Yafie, "Menggagas Fiqh Sosial," Bandung: Mizan, 1994; Sahal Mahfudh, Nuansa Fiqih Sosial (LKiS, 1994).

${ }^{37}$ Anjar Nugroho, "Fikih Kiri: Revitalisasi Usul al-Fiqh untuk Revolusi Sosial," Al-Jami'ah: Journal of Islamic Studies 43, no. 2 (2005): 425-454.

38 Yudi Latif, "Bhineka Tunggal Ika: Suatu Konsepsi Dialog Keragaman Budaya”, dalam Fikih Kebhinekaan," Jakarta: Mizan, 2015.

${ }^{39}$ Madjid, “Keharusan pembaruan pemikiran Islam dan masalah integrasi umat," 3-4. 
setidaknya dilakukan liberarisasi, intellectual freedom atau Kebebasan Berpikir dan "Idea of Progress" dan Sikap Terbuka.

Sekularisasi menurut Madjid tidaklah dimaksudkan sebagai penerapan sekularisme dan mengubah kaum Muslimin menjadi sekularis. Tetapi dimaksudkan untuk menduniawikan nilai-nilai yang sudah semestinya bersifat duniawi, dan melepaskan umat Islam dari kecenderungan untuk meng-ukhrawi-kannya. Sementara kebebasan berpikir dan menyatakan pendapatlah merupakan salah satu bentuk kebebasan yang paling berharga. Umat Islam menurut Madjid seharusnya mempunyai kemantapan kepercayaan bahwa semua bentuk pikiran dan ide, betapapun aneh namun harus tetap dinyatakan, karena tidak jarang, dari pikiran-pikiran dan ide-ide yang semula diperkirakan salah dan palsu itu, ternyata belakangan terbukti benar. Kenyataan itu merupakan pengalaman setiap gerakan pembaruan, perseorangan maupun organisasi, di mana pun. ${ }^{40}$ Adapun idea of progress bertitik-tolak dari konsepsi, atau doktrin, bahwa manusia pada dasarnya adalah baik, suci, dan cinta kepada kebenaran atau kemajuan (manusia diciptakan Allah dalam fitrah dan berwatak hanîf). Oleh karena itu, salah satu bukti adanya idea of progress munculnya kepercayaan akan masa depan manusia dalam rangkaian perjalanan sejarahnya. Maka tidak perlu lagi khawatir akan perubahan-perubahan yang selalu terjadi pada tata-nilai duniawi manusia. Sebetulnya, sikap reaksioner dan tertutup terbit dari rasa pesimis terhadap sejarah. Oleh karena itu, berpegang teguh kepada idea of progress merupakan sikap mental yang terbuka, yakni berupa kesediaan menerima dan mengambil nilai-nilai (duniawi) dari mana pun berasal asal mengandung kebenaran. ${ }^{41}$

Demikian pemikiran Islam di Indonesia dalam seperempat abad terakhir, telah mengalami kemajuan yang berarti melalui pengayaan tema yang ditampilkannya. Tema itu tidak lagi berputar-putar pada mata rantai teosentrik dan bersifat politis-ideologis semata, melainkan telah memasuki ruang yang bersifat kultural, teologis, antroposentrik dan filosofis-sosiologis. Apabila muncul Konsep Islam Nusantara, maka menurut Muhadjir, muncul pula Fiqih Nusantara hasil dialektika teks-teks syariat dan budaya, juga realitas di (daerah) setempat. ${ }^{42}$

Wacana fikih sosial yang telah dikembangkan Kiai Sahal bukan lah semata-mata produk hukum dan pengembaraan intelektual yang panjang, namun juga merupakan perangkat metodologi untuk mensikapi problem umat. ${ }^{43}$

Meskipun banyak kalangan menyebut perkembangan tumbuhnya pemikiranpemikiran baru sebagaimana dikemukakan di atas sebagai kerja indonesianist ketimbang

${ }^{40}$ Walaupun menurut Madjid, masih harus diakui bahwa pikiran-pikiran yang berdasarkan Islam itu dapat menyelesaikan problem-problem itu sebaik-baiknya, jika disesuaikan, dipersegar, diperbarui, dan diorganisasikan (dikoordinasikan), untuk membuat ide-ide sejalan dengan kenyataan-kenyataan zaman sekarang.

${ }^{41}$ Madjid, "Keharusan pembaruan pemikiran Islam dan masalah integrasi umat," 8.

${ }^{42}$ Afifuddin Muhadjir, Khatib Syuriah PB NU. Menurutnya Fiqih Nusantara adalah paham dan prespektif keislaman di bumi Nusantara sebagai hasil dialektika teks-teks syariat dan budaya, juga realitas setempat. "Apa yang Dimaksud dengan Islam Nusantara? I NU Online," diakses 22 Oktober 2017, http://www.nu.or.id/post/read/59035/apa-yang-dimaksud-dengan-islam-nusantara.

${ }^{43}$ Ahmad Faisal, “Nuansa Fiqh Sosial KH. MA. Sahal Mahfudh,” Al-Ulum 10, no. 2 (2017): 363-382. 
islamicist, tetap saja perkembangan itu cukup unik dan memberikan kontribusi dalam penyelenggaraan Islam di Indonesia. Dalam konteks yang sama, berkembangnya pemikiran pembaruan di kalangan NU yang oleh Mitsuo Nakamura diberi label "tradisional", ${ }^{44}$ pemikiran keagamaan (baca: wacana berfiqh) dengan pendekatan baru tersebut, tentu saja relatif baru. Yang menarik, bahwa ternyata dinamika tersebut berjalan tanpa harus terjadi benturan-benturan, baik dengan tradisi maupun dengan sistem kultur yang mengitarinya.

\section{Kesimpulan}

Islam memuat nilai-nilai dasar dan universal berkenaan dengan kejujuran, persamaan, persaudaraan, amanah, musyawarah dan aspek-aspek lainnya yang ditujukan agar tercipta tatanan kehidupan sosial kemasyarakatan yang beradab (civil society). Islam adalah agama yang hanafiah-samhah, lurus-mudah dan tidak memberatkan pada umatnya. Dalam perjalanannya, ajaran Islam selalu sesuai dan dapat disesuaikan dengan kondisi struktur sosial, budaya dan letak geografis dimana masyarakat tersebut berada. Oleh karenanya, untuk menumbuhkan dan menghidupkan ruh Islam agar tetap dinamis, responsif dan punya adaptabilitas yang tinggi terhadap tuntutan perubahan dan keragaman dalam masyarakat khususnya di Indonesia, maka perlu dilakukan dengan cara menghidupkan dan menggairahkan kembali diskusi pemikiran intelektual di kalangan umat Islam. Pada posisi ini hasil pemikiran keagamaan (ijtihad) merupakan inner dynamic bagi lahirnya perubahan untuk mengawal cita-cita universalitas Islam sebagai sistem ajaran yang shalihun li kulli zaman wal makan. Sekaligus, membumikan sejumlah wacana kehidupan dan keagamman dapat diaplikasikan pada tataran lokal (nusantara).

${ }^{44}$ Mitsuo Nakamura, "The radical traditionalism of the Nahdlatul Ulama in Indonesia: A personal account of the 26th National Congress, June 1979, Semarang," 1981; Penjelasan tentang konteks sosio-politik sikap tradisionalis NU dapat dibaca misalnya dalam Martin Van Bruinessen, NU: tradisi, relasi-relasi kuasa, pencarian wacana baru (PT LKiS Pelangi Aksara, 1994), 51. 


\section{Referensi}

Abdurrahman, Moeslim. Islam Transformatif, Jakarta: Pustaka Firdaus. 1995. Jakarta: Pustaka Firdaus, 1995.

Aji, A.M. Rasionalitas ijtihad Ibn Rusyd: kajian atas fiqh jinayat dalam kitab "Bidayat al-Mujtahid wa Nihayat al-Muqtashid, Bogor: Pustaka Pena Ilahi, 2010.

Aji, A.M.; Yunus, N.R. Basic Theory of Law and Justice, Jakarta: Jurisprudence Institute, 2018.

Azra, Azyumardi. Islam Nusantara: Jaringan Global dan Lokal. Mizan, 2002.

Azra, Azyumardi. Pergolakan Politik Islam: dari Fundamentalisme, Modernisme hingga Posmodernisme. Jakarta: Paramadina, 1996.

Bakri, Syamsul. "Agama, Persoalan Sosial, dan Krisis Moral." KOMUNIKA 3, no. 1 (2009): 37-45.

Beckford, James A. New religious movements and rapid social change. Sage, 1986.

Bruinessen, M. M. van. “Gerakan sempalan di kalangan umat Islam Indonesia: latar belakang sosial-budaya," 2007.

Burhanuddin, Nunu. “Tipologi Gerakan Sempalan di Kalangan Umat Islam Indonesia: Analisis Sosiologis dan Fungsional." Dalam Annual Conference on Islamic Studies in Banjarmasin, South Kalimantan, Indonesia, on, 1-4, 2010.

Faisal, Ahmad. “Nuansa Fiqh Sosial KH. MA. Sahal Mahfudh.” Al-Ulum 10, no. 2 (2017): 363-382.

Fathullah, Fathullah. "Hukum Islam dan Perubahan Sosial." As-Syari'ah: Jurnal Hukum Islam 2, no. 2 (2016): 35-49.

Fawaid, Ah. "Tradisi Ijtihad: Mengembalikan Semangat Progresivitas Islam." ULUL ALBAB Jurnal Studi Islam, 2013.

Fuad, Mahsun. Hukum Islam Indonesia: dari nalar partisipatoris hingga emansipatoris. PT LKiS Pelangi Aksara, 2005.

Harisudin, M. Noor. "Rekonstruksi Fiqh dalam Merespon Perubahan Sosial." AsySyir'ah 50, no. 1 (2016): 81-107.

Imdad, S. H. I. "Hukum Islam dan Perubahan Sosial," t.t.

Jafar, Wahyu Abdul. "Ijtihad Dalam Bentang Sejarah Prakodifikasi Ushul Fiqh.” Nizham Journal of Islamic Studies 2, no. 1 (2017): 44-62.

Khalaf, Abdul Wahab. “Ilm usul al-Fiqh.” Kuwait: Darul Qalam, 1978.

Kippenberger, T. “Nothing endures but change.” The Antidote 3, no. 4 (1998): 4-5.

Langaji, Abbas. “Dinamika Aliran Keagamaan Sempalan: Tinjauan Perspektif Sosiologi Agama," 2012.

Latif, Yudi. "Bhineka Tunggal Ika: Suatu Konsepsi Dialog Keragaman Budaya”, dalam Fikih Kebhinekaan." Jakarta: Mizan, 2015. 
Madjid, Nurcholish. "Keharusan pembaruan pemikiran Islam dan masalah integrasi umat." Islam: Kemodernan dan Keindonesiaan, 1987, 204-14.

Maggalatung, A.S.; Aji, A.M.; Yunus, N.R. How The Law Works, Jakarta: Jurisprudence Institute, 2014.

Mahfudh, Sahal. Nuansa Fiqih Sosial. LKiS, 1994.

Majid, Mohd Kamil Abd, dan Rahimin Affandi Abdul Rahim. "Perubahan Sosial Dan Impaknya Terhadap Pembentukan Modal Insan Menurut Ibn Khaldun." Jurnal Hadhari 1 (2008): 1-38.

Marius, Jelamu Ardu. “Perubahan Sosial." Jurnal Penyuluhan 2, no. 2 (2006): 125-35.

Masud, Muhammad Khalid. "Filsafat Hukum Islam: Studi tentang Hidup dan Pemikiran Abu Ishaq al-Syathibi, terj." Ahsin Muhammad, cet 1 (1996): 176.

Muid N., Abd. Islam vs Barat: Merajut Identitas yang Terkoyak. Jakarta: Eurabia, 2013.

Mulkhan, Abdul Munir. Teologi kebudayaan dan demokrasi modernitas. Pustaka Pelajar, 1995.

Musa, Ali Masykur. Membumikan Islam Nusantara: Respons Islam terhadap Isu-Isu Aktual, 2014.

Najitama, Fikria. "Sejarah Pergumulan Hukum Islam dan Budaya serta Implikasinya bagi Pembangunan Hukum Islam Khas Indonesia." Al-Mawarid 17 (2007).

Nakamura, Mitsuo. "The radical traditionalism of the Nahdlatul Ulama in Indonesia: A personal account of the 26th National Congress, June 1979, Semarang," 1981.

Nugroho, Anjar. "Fikih Kiri: Revitalisasi Usul al-Fiqh untuk Revolusi Sosial." Al-Jami'ah: Journal of Islamic Studies 43, no. 2 (2005): 425-454.

Rahmat, Jalaluddin. Islam alternatif: ceramah-ceramah di kampus. Mizan, 1988.

Rais, M. Amin. “Tauhid Sosial: Doktrin Perjuangan Muhammadiyah." dalam media Indonesia, Jurnal Universitas Muhammadiyah, Yogyakarta, no. 1 (1996).

Ramadan, Tariq. Islam, the West and the Challenges of Modernity. Kube Publishing Ltd, 2009.

Ramadan, Tariq. Western Muslims and the future of Islam. Oxford University Press, 2003.

Rayner, Susan Elizabeth. "The theory of contracts in Islamic law: a comparative analysis with particular reference to the modern legislation in Kuwait, Bahrain and the United Arab Emirates." University of Cambridge, 1989.

Rusyd, Ibn. Muhammad, Bidayat al-Mujtahid wa Nihayat al-Muqtashid. Beirut: Dar alQalam, 1988.

Sakirman, Sakirman. "Meretas Kebekuan Ijtihad Dalam Konstruksi Fiqih Sosial." Mizani 25 , no. 1 (2015).

Soerjono, Soekanto. “Pokok-Pokok Sosiologi Hukum.” Jakarta: Rajawali Pers, 1980. 
Van Bruinessen, Martin. NU: tradisi, relasi-relasi kuasa, pencarian wacana baru. PT LKiS Pelangi Aksara, 1994.

Wahid, Abdurrahman. "Pribumisasi Islam" dalam Islam Indonesia Menatap Masa Depan." Jakarta: P3M, 1989.

Yafie, Ali. “Menggagas Fiqh Sosial." Bandung: Mizan, 1994.

“Apa yang Dimaksud dengan Islam Nusantara? I NU Online." Diakses 22 Oktober 2017. http://www.nu.or.id/post/read/59035/apa-yang-dimaksud-dengan-islamnusantara. 


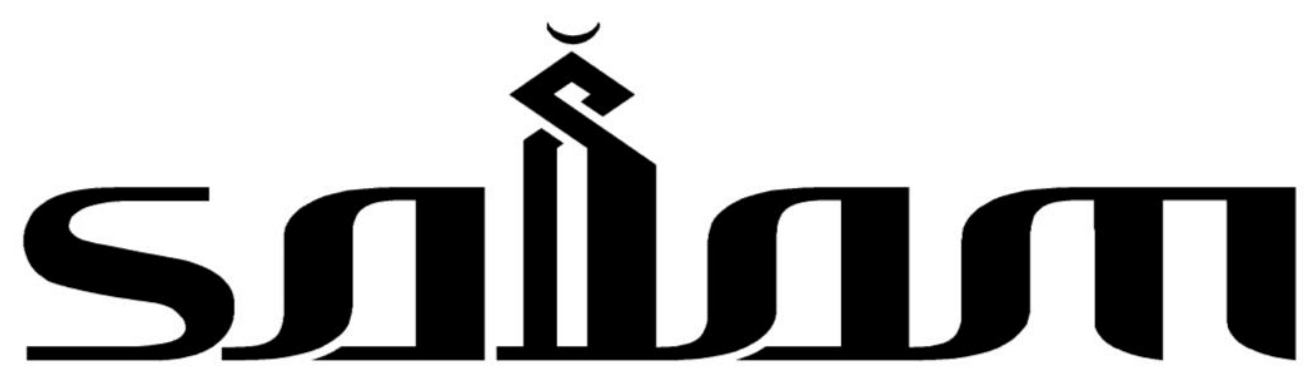

Jumnal Sosial dan Budaya Syar'i

\section{PEDOMAN TEKNIS PENULISAN BERKALA ILMIAH}

1. Artikel adalah benar-benar karya asli penulis, tidak mengandung unsur plagiasi, dan belum pernah dipublikasikan dan/atau sedang dalam proses publikasi pada media lain yang dinyatakan dengan surat pernyataan yang ditandatangani di atas meterai Rp 6000;

2. Naskah dapat berupa konseptual, resume hasil penelitian, atau pemikiran tokoh;

3. Naskah dapat berbahasa Indonesia, Inggris, Arab, maupun bahasa Rusia;

4. Naskah harus memuat informasi keilmuan dalam ranah ilmu hukum Positif;

5. Aturan penulisan adalah sebagai berikut:

a. Judul. Ditulis dengan huruf kapital, maksimum 12 kata diposisikan di tengah (centered);

b. Nama penulis. Ditulis utuh, tanpa gelar, disertai afiliasi kelembagaan dengan alamat lengkap, dan alamat e-mail;

c. Abstrak. Ditulis dalam bahasa Inggris dan Bahasa Indonesia antara 80-120 kata;

d. Sistematika penulisan naskah adalah sebagai berikut:

1) Judul;

2) Nama penulis (tanpa gelar akademik), nama dan alamat afiliasi penulis, dan e-mail;

3) Abstrak ditulis dalam dua bahasa, yaitu bahasa Indonesia dan Inggris, antara 80-120 kata;

4) Kata-kata kunci, antara 2-5 konsep yang mencerminkan substansi artikel;

5) Pendahuluan;

6) Sub judul (sesuai dengan keperluan pembahasan);

7) Penutup; dan

8) Pustaka Acuan (hanya memuat sumber-sumber yang dirujuk dan sedapat mungkin terbitan 10 tahun terakhir).

e. Ukuran kertas yang digunakan adalah kertas HVS 70 gram, ukuran A4, margin: atas $3,5 \mathrm{~cm}$, bawah $3.5 \mathrm{~cm}$, kiri $3,5 \mathrm{~cm}$, dan kanan $3,5 \mathrm{~cm}$;

f. Panjang Naskah antara 13 s.d. 15 halaman, spasi 1, huruf Palatino, ukuran 11;

g. Pengutipan kalimat. Kutipan kalimat ditulis secara langsung apabila lebih dari empat baris dipisahkan dari teks dengan jarak satu spasi dengan ukuran huruf 10 point. Sedangkan kutipan kurang dari empat baris diintegrasikan dalam teks, dengan tanda apostrof ganda di awal dan di akhir kutipan. Setiap kutipan diberi nomor. Sistem pengutipan adalah footnote (bukan bodynote atau endnote). Penulisan footnote menggunakan sistem turabian. Setiap artikel, buku, dan sumber lainnya yang dikutip harus tercantum dalam pustaka acuan;

h. Pengutipan Ayat Alquran dan Hadis. Ayat yang dikutip menyertakan keterangan ayat dalam kurung, dengan menyebut nama surah, nomor surah, dan nomor ayat, seperti (Q.s. al-Mu'min [40]: 43). Pengutipan Hadis menyebutkan nama perawi (H.r. al-Bukhārĩ dan Muslim) ditambah referensi versi cetak kitab Hadis yang dikutip. Hadis harus dikutip dari kitab-kitab Hadis standar (Kutub al-Tis'ah);

i. Cara pembuatan footnote. Footnote ditulis dengan font Palation size 9, untuk pelbagai sumber, antara lain: 
1) Buku: nama utuh penulis (tanpa gelar), judul buku (tempat terbit: penerbit, tahun terbit), cetakan, volume, juz, halaman. Contoh: Soerjono Soekanto, Pokok-pokok Sosiologi Hukum, (Jakarta: Rajawali Pers, 1986), h. 10.

2) Buku terjemahan, contoh: Roscoe Pound, Pengantar Filsafat Hukum: Buku III, diterjemahkan oleh Moh. Radjab, (Jakarta: Bharata, 1963), h. 15;

1) Jurnal, contoh: Nur Rohim, "Kontroversi Pembentukan Perppu No. 1 Tahun 2013 tentang mahkamah konstitusi dalam ranah kegentingan yang memaksa", dalam Jurnal Cita Hukum, Vol. 2, No. 1 (2014), h. 157.

2) Artikel sebagai bagian dari buku (antologi), contoh: Hikmahanto Juwana, "Penegakan Hukum dalam Kajian Law and Development: Problem dan Fundamen bagi Solusi Indonesia", dalam Muhammad Tahir Azhary, Beberapa Aspek Hukum Tata Negara, Hukum Pidana, dan Hukum Islam, (Jakarta: Kencana Prenada Media Gorup, 2012), h. 127.

3) Artikel dari internet, contoh: Ahmad Tholabi Kharlie, "Problem Yuridis RUU Syariah" dalam http://ahmadtholabi.com/2008/03/03/problem-yuridis-ruu-syariah, diunduh pada 20 Maret 2012.

4) Artikel dari majalah, contoh: Susilaningtias, "Potret Hukum Adat pada Masa Kolonial", dalam Forum Keadilan, No. 17, 20 Agustus 2006.

5) Makalah dalam seminar, contoh: Jimly Asshiddiqie, "Kedudukan Mahkamah Konstitusi dalam Struktur Ketatanegaraan Indonesia", Makalah disampaikan dalam Kuliah Umum Fakultas Hukum Universitas Sebelas Maret, Surakarta, pada 2 Maret 2004.

j. Pustaka Acuan: daftar pustaka acuan ditulis sesuai urutan abjad, nama akhir penulis diletakkan di depan. Contoh:

1) Buku, contoh: Soekanto, Soerjono, Pokok-pokok Sosiologi Hukum, Jakarta: Rajawali Pers, 1986.

2) Buku terjemahan, contoh: Pound, Roscoe, Pengantar Filsafat Hukum: Buku III, diterjemahakan oleh Moh. Radjab, Jakarta: Bharata, 1963.

3) Jurnal, contoh: Rohim, Nur, "Kontroversi Pembentukan Perppu No. 1 Tahun 2013 tentang mahkamah konstitusi dalam ranah kegentingan yang memaksa", dalam Jurnal Cita Hukum, Vol. 2, No. 1 (2014).

4) Artikel sebagai bagian dari buku, contoh: Juwana, Hikmahanto, "Penegakan Hukum dalam Kajian Law and Development: Problem dan Fundamen bagi Solusi Indonesia", dalam Muhammad Tahir Azhary, Beberapa Aspek Hukum Tata Negara, Hukum Pidana, dan Hukum Islam, Jakarta: Kencana Prenada Media Gorup, 2012.

5) Artikel yang dikutip dari internet, contoh: Kharlie, Ahmad Tholabi, "Problem Yuridis RUU Syariah" dalam http://ahmadtholabi.com/2008/03/03/problem-yuridis-ruu-syariah, diunduh pada 20 Maret 2012.

6) Majalah, contoh: Susilaningtias, "Potret Hukum Adat pada Masa Kolonial", dalam Forum Keadilan, No. 17, 20 Agustus 2006.

7) Makalah dalam seminar, contoh: Asshiddiqie, Jimly, "Kedudukan Mahkamah Konstitusi dalam Struktur Ketatanegaraan Indonesia", Makalah disampaikan dalam Kuliah Umum Fakultas Hukum Universitas Sebelas Maret, Surakarta, pada 2 Maret 2004.

k. Penutup: artikel ditutup dengan kesimpulan;

I. Biografi singkat: biografi penulis mengandung unsur nama (lengkap dengan gelar akademik), tempat tugas, riwayat pendidikan formal (S1, S2, S3), dan bidang keahlian akademik;

6. Setiap naskah yang tidak mengindahkan pedoman penulisan ini akan dikembalikan kepada penulisnya untuk diperbaiki.

7. Naskah sudah diserahkan kepada penyunting, selambat-lambatnya tiga bulan sebelum waktu penerbitan (April, Agustus. dan Desember) dengan mengupload pada laman OJS jurnal pada alamat http://journal.uinjkt.ac.id/index.php/salam atau dikirim langsung via e-mail ke: jurnal.salam@gmail.com atau nurrohimyunus@uinjkt.ac.id..] 


\section{Indexed by :}
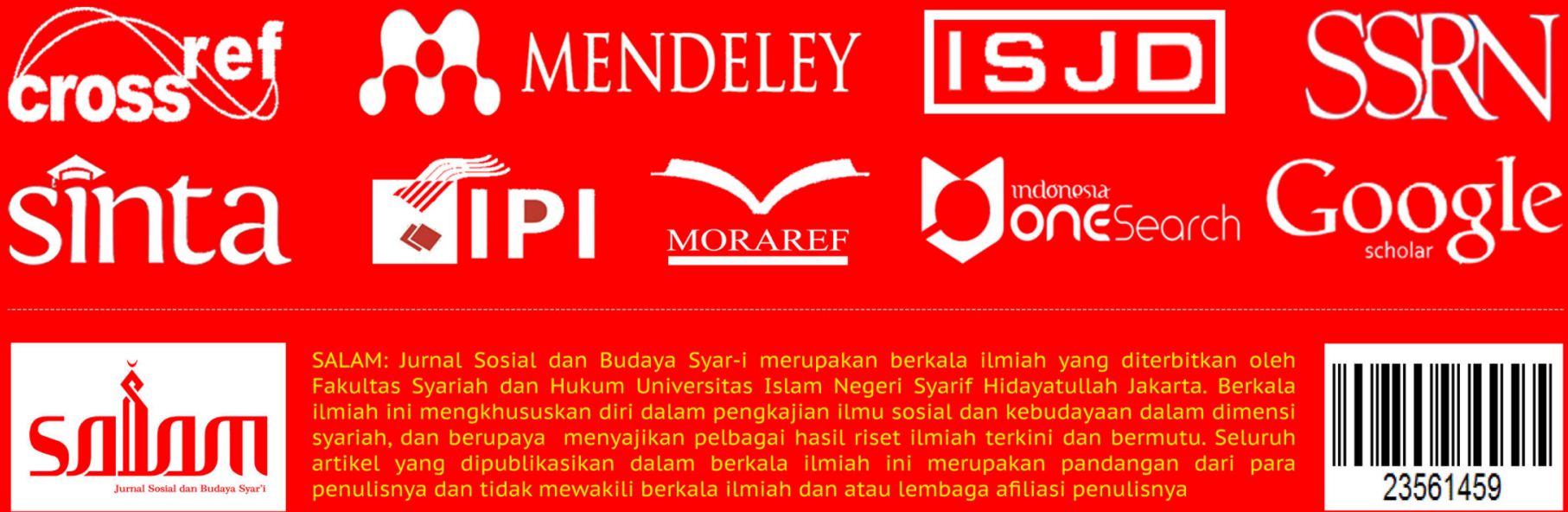

SALAM: Jurnal Sosial dan Budaya Syar-i merupakan berkala ilmiah yang diterbitkan oleh Fakultas Syariah dan Hukum Universitas Islam Negeri Syarif Hidayatullah Jakarta. Berkala ilmiah ini mengkhususkan diri dalam pengkajian ilmu sosial dan kebudayaan dalam dimensi syariah, dan berupaya menyajikan pelbagai hasil riset ilmiah terkini dan bermutu. Seluruh artikel yang dipublikasikan dalam berkala ilmiah ini merupakan pandangan dari para penulisnya dan tidak mewakili berkala ilmiah dan atau lembaga afiliasi penulisnya

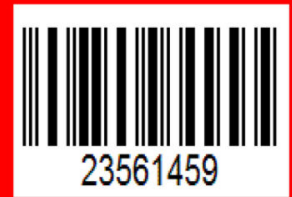

